\title{
Correction to: Rituals and explorations in mathematical teaching and learning: introduction to the special issue
}

\author{
Einat Heyd-Metzuyanim ${ }^{1}$ (D) $\cdot$ Mellony Graven $^{2}$
}

Published online: 17 October 2019

(C) The Author(s) 2019

\section{Correction to: Educational Studies in Mathematics (2019) 101(2):141-151 https://doi.org/10.1007/s10649-019-09890-x}

The article "Rituals and explorations in mathematical teaching and learning: introduction to the special issue", written by Einat Heyd-Metzuyanim and Mellony Graven, was originally published Online First without Open Access. After publication in volume 101, issue 2, page 141-151 the author decided to opt for Open Choice and to make the article an Open Access publication. Therefore, the copyright of the article has been changed to (C) The Author(s) 2019 and the article is forthwith distributed under the terms of the Creative Commons Attribution 4.0 International License (http://creativecommons.org/licenses/by/4.0/), which permits use, duplication, adaptation, distribution and reproduction in any medium or format, as long as you give appropriate credit to the original author(s) and the source, provide a link to the Creative Commons license, and indicate if changes were made.

The original article has been corrected.

Open Access This article is distributed under the terms of the Creative Commons Attribution 4.0 International License (http://creativecommons.org/licenses/by/4.0/), which permits unrestricted use, distribution, and reproduction in any medium, provided you give appropriate credit to the original author(s) and the source, provide a link to the Creative Commons license, and indicate if changes were made.

Publisher's note Springer Nature remains neutral with regard to jurisdictional claims in published maps and institutional affiliations.

The online version of the original article can be found at https://oi.org/10.1007/s10649-019-09890-x

Einat Heyd-Metzuyanim

einathm@technion.ac.il

1 Faculty of Education in Science and Technology, Technion-Israel Institute of Technology, 3200003 Haifa, Israel

2 Rhodes University, Grahamstown 6139, South Africa 